\title{
The Origin and Evolution in Trillium \\ 2. Chromosome Variation of Trillium undulatum in North America
}

\author{
Ichiro Fukuda \\ The Asian Ecology-Evolution Institute, Tokyo 192-0913, Japan \\ Accepted August 13, 2001
}

\begin{abstract}
Summary Chromosome analysis by the cold-induced heterochromatin banding method was carried out for populations of the American species Trillium undulatum. The banded karyotypes of individuals within the species were polymorphic. Furthermore, a comparative study showed that the genome of T. undulatum has a close relationship with the $\mathrm{G}$ genome of the Asian species $T$. govanianum. It is an interesting evolutionarily problem to speculate on how the American and Asian species of Trillium species connected in both continents across the Pacific Ocean.
\end{abstract}

Key words Heterochromatic banding chromosomes, Trillium undulatum, Population analysis, Comparative study, North America, Asia.

Trillium undulatum Willdenow (Fig. 1) is distributed from New Brunswick in Canada to Georgia in the United States and extends throughout the Appalachian mountain range (Fig. 2). The plants grow in a sandy and highly acidic loam under deciduous or deciduous-evergreen forests. In late spring the flowers bloom and show their most attractive white petals with a blazing red center base (Fig. 1A). This flower is commonly called the "Painted Trillium". In late summer the fruits ripen into a bright red color.

The Somatic chromosome number for T. undulatum was first recorded by Wilson and Boothroyd (1941) as $2 n=2 x=10$. The chromosomes of this species show the heterochromatic banding patterns after the cold-treatment (Darlington and La Cour 1938, 1940).

The purpose of this article was to study the chromosome banding-karyotypes within the species of T. undulatum. From this study, it has been very interesting to find that the unique karyotypes of T. undulatum are correlated with the Himalayan species T. govanianum in Asia. How the characteristics of these species have developed evolutionarily has been approached in this study from both the chromosomal and morphological viewpoints.

\section{Materials and methods}

For chromosome investigation materials of $T$. undulatum were collected from 2 localities, at St. Eugene, Prescott Co., Ontario, Canada and at Holland, Erie Co., New York in U.S.A.

Chromosome experiments were carried out on meristematic cells of the root tip after a coldtreatment $\left(0^{\circ} \mathrm{C}\right)$ for $96 \mathrm{~h}$ in a refrigerator (Darlington and La Cour 1938, 1940, Kurabayashi 1952). The root tips were fixed in $\mathrm{La}$ Cour $2 \mathrm{BE}$ for $15 \mathrm{~min}$, hydrolyzed in $1 \mathrm{~N} \mathrm{HCl}$ at $60^{\circ} \mathrm{C}$ for $12 \mathrm{~min}$ and stained in Feulgen solution for $60 \mathrm{~min}$. Squash preparations were made in $45 \%$ acetic acid. Chromosome data for a comparative study was from the information that had been recorded for $T$. govanianum in Nepal (Fukuda 2001).

Specimens used for carrying out comparative studies for morphological analyses were collected at St. Eugene, Ontario, Canada for T. undulatum, at Chiley-La, Bhutan for T. govanianum, at

*Corresponding author, e-mail: trifukuda@pop21.odn.ne.jp 

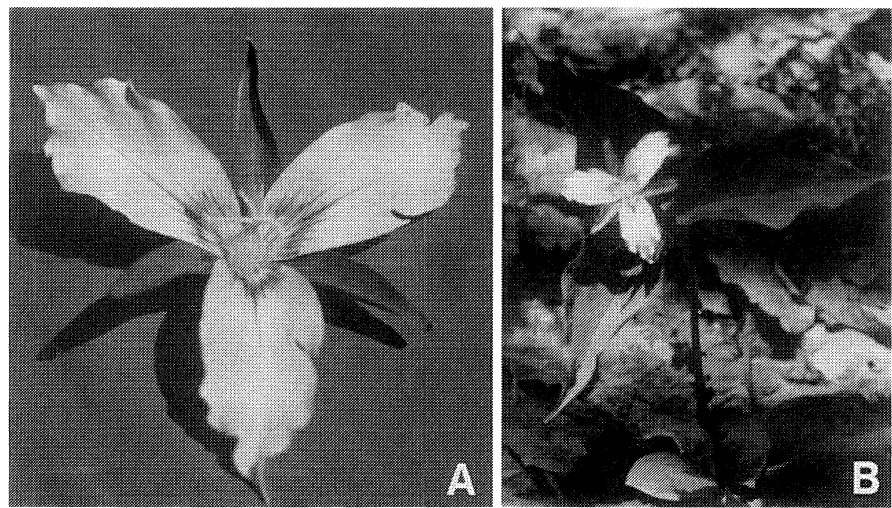

Fig. 1. Photographs of Trillium undulatum. A. Close-up photograph of the flower. $\times 1.5$. B. Habitat photograph. $\times 0.5$.

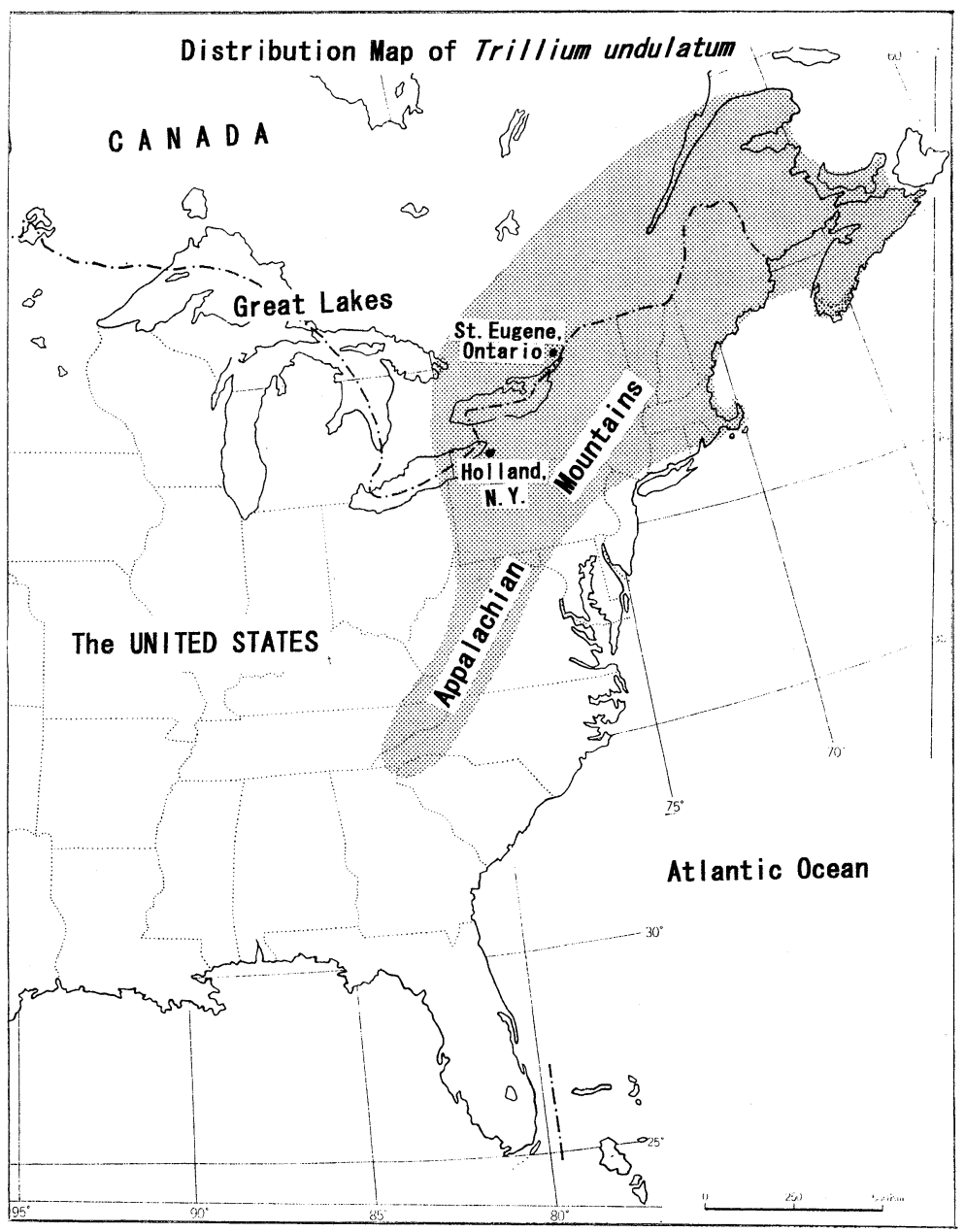

Fig. 2. Geographical distribution of Trillium undulatum. 
Bhuma, Kushiro, Japan for T. camschatcense, and at Ste. Anme de Bellevue, Quebec, Canada for T. erectum. Sample number was over 20 specimens in each locality.

\section{Chromosome analyses}

Cold-induced heterochromatic banding karyotypes for T. undulatum are clearly shown in Fig. 3. The chromosome composition in each individual is denoted by the make-up of the chromosomes and numbers are given to the different banding types. For example, sample No. 6 (Fig. 3a), showing all 10 chromosomes is denoted as, A5, A5, B3, B3, C6, C6, D2, D6, and E4, E4 (Fig. 3b).

Fig. 4 illustrates schematic drawings of the chromosome-banding karyptypes found in T. undulatum collections. The dark areas depict euchromatic segments, whereas the white areas illustrate heterochromatic segments. In

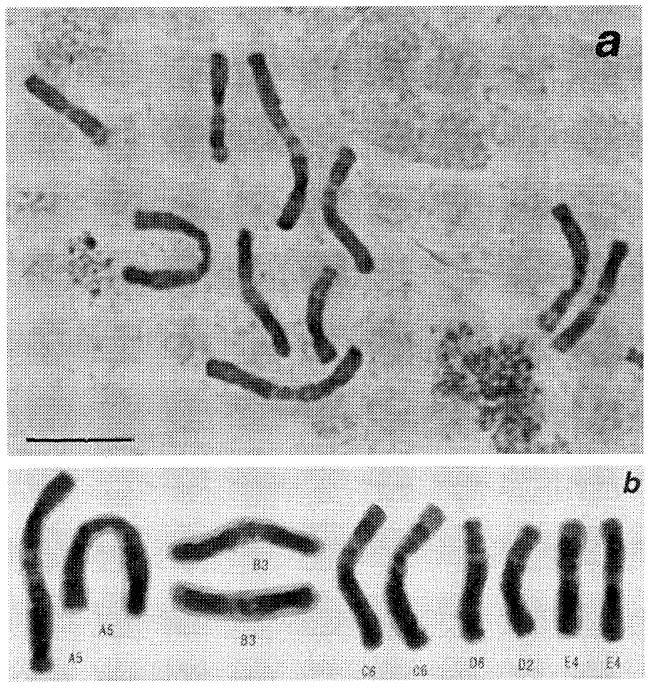

Fig. 3. Chromosome photographs of Trillium undulatum. a. Karyotypes $2 n=10$ Bar represents $10 \mu \mathrm{m}$. b. Showing the heterochromatic bands. Sample No. 6 composed of A5, A5, B3, B3, C6, C6, D6, D2 and E4, E4.

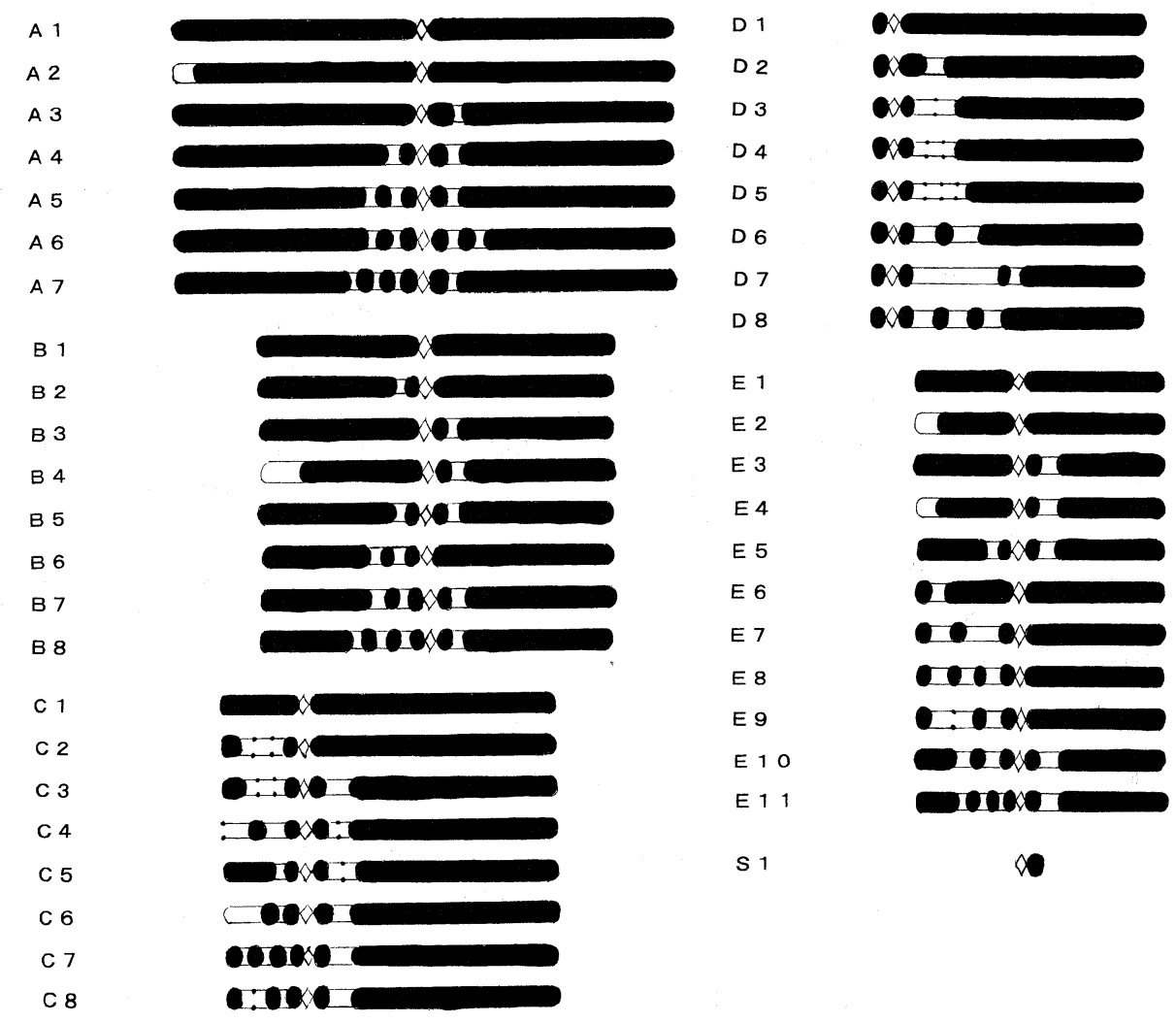

Fig. 4. Diagramatic illustration of the karyotype of Trillium undulatum showing the heterochromatic banding patterns for chromosome A, B, C, D and E. S shows the supernumerary chromosome. 
Table 1. Chromosome compositions of natural populations in Trillium undulatum

\begin{tabular}{|c|c|c|c|c|c|c|}
\hline Locality & \multicolumn{5}{|c|}{ St. Eugene, Ontario, Canada } & $1998 *$ \\
\hline Sample No. & \multicolumn{5}{|c|}{ Chromosome composition } & \\
\hline 1 & $\mathrm{~A}-1 \cdot 1$ & B- $1 \cdot 2$ & $\mathrm{C}-1 \cdot 1$ & $\mathrm{D}-1 \cdot 2$ & $\mathrm{E}-1 \cdot 3$ & \\
\hline 2 & $\mathrm{~A}-3 \cdot 4$ & B-5 5 & $\mathrm{C}-2 \cdot 2$ & $\mathrm{D}-6 \cdot 8$ & $\mathrm{E}-1 \cdot 5$ & \\
\hline 3 & $A-4 \cdot 6$ & $\mathrm{~B}-3 \cdot 4$ & $C-6 \cdot 6$ & $\mathrm{D}-6 \cdot 6$ & $\mathrm{E}-4 \cdot 4$ & \\
\hline 4 & $A-3 \cdot 4$ & $B-4 \cdot 7$ & $\mathrm{C}-4 \cdot 4$ & $\mathrm{D}-1 \cdot 2$ & $\mathrm{E}-2 \cdot 3$ & \\
\hline 5 & $\mathrm{~A}-2 \cdot 2$ & $\mathrm{~B}-2 \cdot 5$ & $\mathrm{C}-5 \cdot 5$ & $\mathrm{D}-4 \cdot 4$ & $\mathrm{E}-3 \cdot 3$ & S-1 \\
\hline 6 & $A-5 \cdot 5$ & $\mathrm{~B}-3 \cdot 3$ & $C-6 \cdot 6$ & $\mathrm{D}-2 \cdot 6$ & $\mathrm{E}-4 \cdot 4$ & \\
\hline 7 & $\mathrm{~A}-2 \cdot 3$ & $\mathrm{~B}-2 \cdot 6$ & $\mathrm{C}-5 \cdot 5$ & $\mathrm{D}-4 \cdot 4$ & $E-3 \cdot 3$ & S-1 \\
\hline 8 & $A-3 \cdot 7$ & $\mathrm{~B}-5 \cdot 8$ & $\mathrm{C}-3 \cdot 3$ & $\mathrm{D}-4 \cdot 5$ & $\mathrm{E}-9 \cdot 10$ & \\
\hline 9 & $A-5 \cdot 5$ & $B-2 \cdot 4$ & $C-6 \cdot 6$ & $D-6 \cdot 6$ & E-4.4 & \\
\hline 10 & $\mathrm{~A}-1 \cdot 3$ & $\mathrm{~B}-2 \cdot 2$ & $C-6 \cdot 6$ & $D-3 \cdot 4$ & $\mathrm{E}-6 \cdot 6$ & \\
\hline Total & & & & & & 10 \\
\hline Locality & & & New Yo & A. & & 1960 \\
\hline \multicolumn{7}{|l|}{ Sample No. } \\
\hline 1 & A-1 1 & B- $1 \cdot 1$ & $\mathrm{C}-7 \cdot 7$ & D-7.7 & $\mathrm{E}-7 \cdot 7$ & \\
\hline 2 & $A-1 \cdot 1$ & B-1 11 & $C-6 \cdot 8$ & $D-6 \cdot 6$ & E-8.9 & \\
\hline Total & & & & & & 2 \\
\hline
\end{tabular}

total for T. undulatum, 7 karyotypes were found in chromosome A, 8 karyotypes in chromosome B, 8 karyotypes in chromosome C, 8 karyotypes in chromosome D and 11 karyotypes in chromosome E. In addition in T. undulatum, one telocentric supernumerary chromosome was found.

From the results in this study on the chromosome banding patterns for T. undulatum, the chromosome composition found for each individual sample is given in Table 1.

From the data presented, it is clearly recognized that the pattern of the chromosome banding karyotypes of T. undulatum show considerable variation. The breeding system in a population is an important factor on chromosome variation because autogamy and cross-fertilizing breeding system control and limit gene follow in a population and eventually bring about different population structures and evolutionary trends (Baker 1951, Grant 1981).

Now, the inbreeding coefficient can be estimated for the means of chromosome variation from the proportion of hetero-homozygotes in the population according to the following formula (Wright 1969, Fukuda 1990):

$F=\left(H-H_{o}\right) / H$

Where $H_{o}=1-\sum_{i} p_{i}^{2}$

in which $H$ is the observed proportion of heterozygotes:

$H_{o}$ is the observed proportion of homozygotes:

$P_{i}$ is the frequency of $i$ in the chromosome banding karyotype.

Generally the American Trillium species, T. grandiflorum, T. erectum, T. recurvatum, and T. ovatum have a comparatively homogeneous banded karyotype in contrast to the Asian T. camschtcense (Fukuda 1969, 1970, 1988, 1989). Up to the present time the inbreeding coefficient $(F)$ has 
been calculated for several American Trillium species (Fukuda 1990). Now, in this reseearch, data for T. undulatum has been added.

Table 2 shows the inbreeding coefficient for the American Trillium species including $T$. undulatum. As shown in this table, T. undulatum has the lowest $F$ value. Among the American Trillum species, this highly out-breed feature is an evolutionary characteristic for $T$. undulatum.
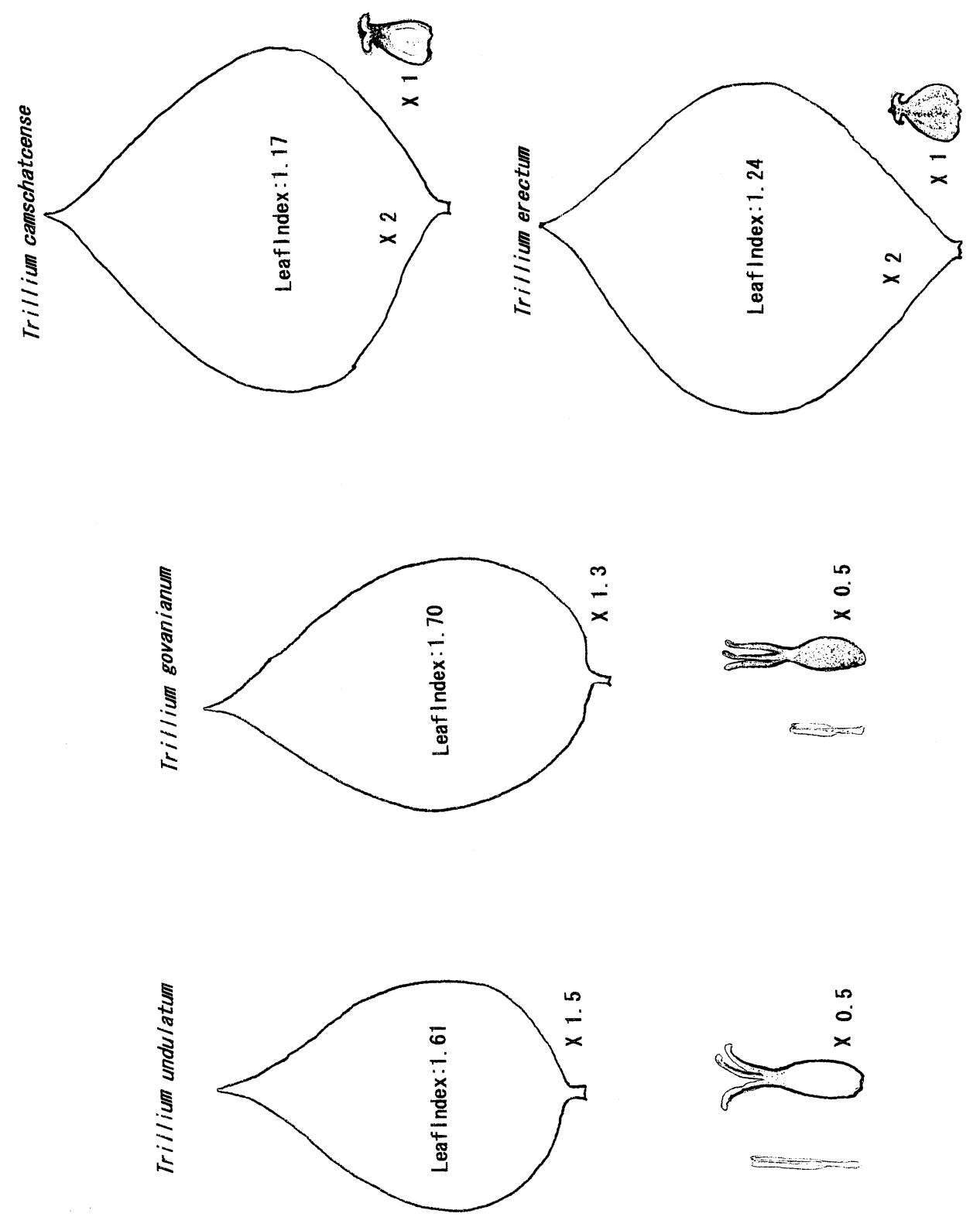

Fig. 5. Comparative shapes of leaves and ovary organs of T. undulatum, T. govanianum, T. camschatcense and $T$. erectum. 
Morphological analysis

T. undulatum has 3 ovate leaves, acuminate at the apices and rounded at the bases. This leaf shape closely resembles that of the Himalayan species $T$. govanianum (Fukuda 2001).

In Fig. 5 the leaf shapes of T. undulatum and T. govanianum, and also the Asian species $T$. camschatcense, and the American species T. erectum are shown. As may be seen from these figures, the leaf shape of $T$. undulatum most closely resembles that of T. govanianum. Leaf index has been recorded from over 20 specimens in each species as $T$. undulatum $=1.61, T$. govanianum $=1.70, T$. camschatcense $=1.17$, and $T$. erectum $=1.24$. The value also shows that the relationship between $T$. undulatum and T. govanianum is greater than that of the other species.

Although the petal and sepal shapes of T. undulatum and T. govanianum are different, but the ovary and stigma are more closely similar than those found in T. camschtcense and T. erectum as shown in Fig. 5. The author already reported that T. undulatum is a diploid species and that $T$. govanianum is an allotetraploid species that originated from hybridization between species Trillium and Daiswa species (Fukuda 2001). However, it is very interesting to note the correspondence in morphological characters between T. undulatum and T. govanianum.

It is also remarkable that the fruits of $T$. undularum and T. govaniatum are globose with dark red center although $T$. grandiflorum and $T$. camschatcense in this respect are greenish.

\section{Comparative chromosomal analysis in T. undulatum and T. govanianum}

For a number of years, the author had been collected the cold-induced chromosome banding data for populations of $T$. erectum, $T$. grandiflorum, $T$. ovatum, $T$. recurvatum and $T$. camschatcense (Fukuda 1969, 1970, 1988, 1989, Fukuda and Kozuka 1958, Fukuda and Grant 1979) and T. govanianum, T. undulatum (Fukuda 2001, and in this paper). Comparative studies of the chromosome banding karyotypes for these seven species were carried out. As the result it was found to denote the correspondence between T. undulatum and T. govanianum, G genome has been established.

Fig. 6 shows the similarity in the chromosome figures of T. undulatum and T. govanianum, $\mathrm{G}$ genome. In chromosome A, T. undulatum A3 and T. govanianum A1 has one heterochromatic segment similar on the left chromosome arm. The chromosomes of both specie show almost the same karyotypes. In chromosome C, T. undulatum $\mathrm{C} 3$ resembles that of the T. govanianum $\mathrm{C} 1$ chromosome. In chromosome D, T. undulatum D7 also resembles the T. govanianum D1 chromosome. In

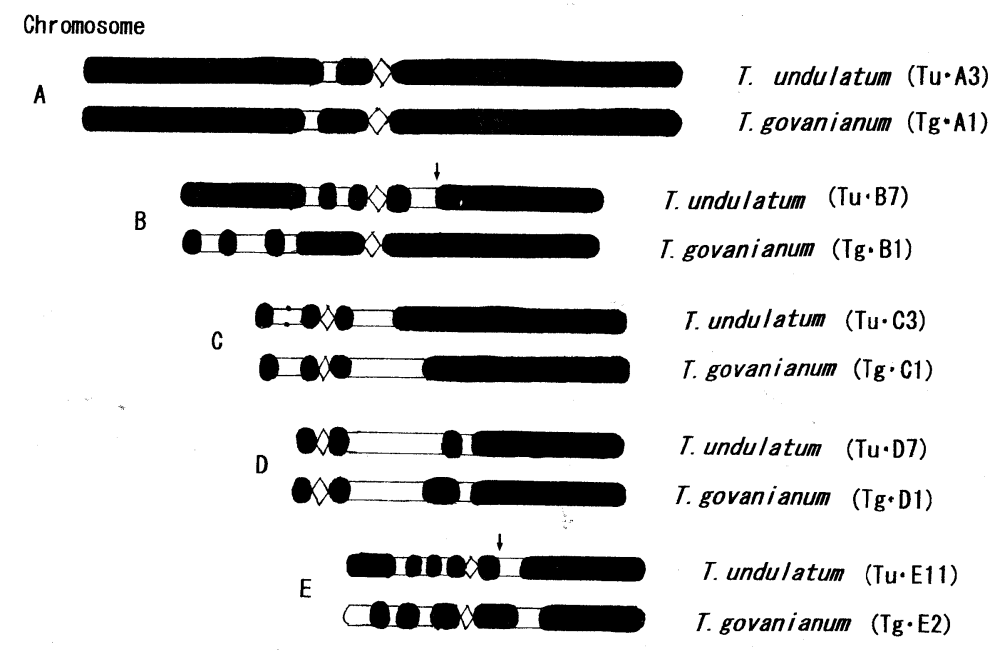

Fig. 6. Chromosome banding karyotypes in T. undulatum and T. govanianum, G genome. 
chromosome B, T. undulatum B7 and T. govanianum B1 have 3 heterochromatic segments in common. When breakage occurred on the T. undulatum B7 chromosome, indicated by the arrow, and reunited on the opposite side, it produced the T. govanianum B1 chromosome. In the same manner, chromosome $\mathrm{E}$ of both species have 4 heterochromatic segments. When breakage occurred the $T$. undulatum E11 chromosome, as indicated by the arrow, and reunited in the opposite side, it formed the T. govanianum E2 chromosome.

From these data it is considered that both genomes of $T$. undulatum and T. govanianum $\mathrm{G}$ have chromosome-banding karyotypes in common. This is a very interesting phenomenon the evolutionary events in terms of chromosome participation in speciation.

\section{Discussion}

By means of chromosomal and morphological analyses the conclusion has been reached that the relationship between T. undulatum and T. govanianum is much closer than that with the other species. Information on the morecular level has recently been concerned with this problem. The mat $K$ and $r b c L$ chloroplast genes and amino acids sequences also showed the affinity of $T$. undulatum and T. govanianum separating these species phylogenetically from other Trillium species (Osaloo et al. 1999, Osaloo and Kawano 1999).

Now the most interesting problem evolutionally is how both species were geographycally connected at one time and why they are separated at the present time. As mentioned earlier, T. undulatum is distributed in eastern North America but T. govanianum is located in the Himalayan mountain region in southern Asia. On the other particulars, T. undulatum is a diploid species but T. govanianum is a tetraploid species. Generally, polyploid species are of more recent origin than diploid species. Is T. govanianum really newer, that is a more recently arisen species, than T. undulatum? We must look at the paleological data in Asia and North America.

In the Cretaceous age, Sequoia, Metasequoia, Taxodium, Alnus, Betula, Fagus, Quercus, Acer, Tilia and Cercidiphyllum were distributed in Lat. $30-70^{\circ} \mathrm{N}$ in Asia and North America (Axelrod 1961, Tsukada 1974). It was the equable warm and wet climates in that area in the Northern Hemisphere. In the Eocene, of the Tertiary period, the flora of central and southern Asia and North America had produced the similar large floral belt in both continents across the Pacific Ocean (Axelrod 1958, Wolfe 1967). Although there are no paleological records on fossils or pollens for Trilliaceae plants, many monocotyledonous plants arose in the upper Cretaceous and developed in the Tertiary period (Stewart 1983, Takhtajan 1981, Stebbins 1974). The present Trillium species were associated with most of the abundant broad-leaved trees and several conifers, and grew mostly in humid habitats (Fukuda and Channell 1975). It is considered that T. undulatum might have developed and spread from North America to Central Asia under the floristic connection of the forests in the Tertiary period. As a first step, plants of T. undulatum that arrived to Central Asia were diploid. This species corresponds to T. govanianum, G genome. The species grew well in Central Asia in the Miocene and Pliocene periods which had a warm and cool climate but in Pleistocene, Quatemary periods, a strong cold and dry climate spread over the northern hemisphere (Flint 1957, Dunbar 1960, Roberts 1989). An immense glacier ice sheet spread down through Asia and North America. The Laurentian Ice Sheet covered in the Great Lakes region but the southern Appalachian mountain region escaped (Watts 1979). On the other hand, the great glacier did not covered the Central Asian region but instead the Asian region received severe cold and dry climatic conditions which affected living organisms (Pope 1995, Bar-yosef 1995). Especially the flora in an inland Asia was greatly changed by the intense sever cold and dry conditions. As established in Part 1 of this Trillium series (Fukuda 2001), in which the origin of tetraploid T. govanianum was established a result of polyploidization from the diploid Trillium species by overcoming bad conditions. This resulted in the survival of T. govanianum in perpetuity (Fukuda 2001, Stebbins 1971, 1974). Chromosomes of T. 
undulatum and T. govanianum tell us such a dramatic history on the evolutionary pathway from North America to Asia.

At last, I remember the words of Prof. Hitoshi Kihara,

"The history of the earth is recorded in the layers of its crust, The history of all organisms is inscribed in the chromosomes"

(Kihara 1975)

This observation invokes profound thought.

\section{Acknowledgements}

The late Prof. Masataka Kurabayashi, Hokkaido University, Sapporo, Japan initiated this research for Trillium undulatum. Prof. Kurabayashi collected the materials from Holland, New York. The materials from St. Eugene, Ontario were collected by myself with the help of Mr. Peter Chen, a Canadian gardener. Prof. William F. Grant, McGill University, Montreal, Canada made helpful comments in reviewing this manuscript. I gratefully acknowledge these contributions. I am pleased to have successfully completed this study.

\section{References}

Axelrod, D. I. 1958. Evolution of the Madro-Tertiary geoflora. Bot. Rev. 24: 433-509.

- 1961. The Evolution of Flowering Plants. In: Tax, S. (ed.). The Evolution of Life. Chicago Univ. Press, Chicago. pp. $227-305$.

- 1966. Origin of deciduous and evergreen habits in tempolate forests. Evolution 20: 1-15.

Baker, H. G. 1951. Hybridization and natural gene flow between higher plants. Biol. Rev. 20: 302-337.

Bar-Yosef, O. 1995. The Role of Climate in the Interpretation of Human Movements and Cultural Transformations in Western Asia. In: Vrba, E. S. et al. (eds.). Paleoclimate and Evolution. Yale Univ. Press, New Haven.

Darlington, C. D. and La Cour, L. F. 1938. Differential reactivity of the chromosomes. Ann. Bot. N. S. 2: $615-625$.

— and - 1940. Nucleic acid stervation of chromosomes of Trillium. J. Gen. 40: 185-213.

Dunbar, C. O. 1960. Historical Geology. John Wiley., New York.

Flint, R. F. 1957. Glacial and Pleistocene Geology. John Wiley, New York.

Fukuda, I. 1969. Chromosome compositions of natural populations in Trillium ovatum. Science Reports of Tokyo Woman's Christian College 7-11: 110-137.

- 1970. Chromosome compositions of the southern populations in Trillium kamtschaticum. Science Reports of Tokyo Woman's Christian Univ. 12-14: 159-174.

- 1988. Chromosome compositions of natural populations in Trillium erectum. Science Reports of Tokyo Woman's Christian Univ. 76-79: 943-961.

- 1989. Chromosome variation and reproductive system in a population of sessile-flowered Trillium recurvatum. Science Reports of Tokyo Woman's Christian Univ. 80-86: 987-994.

- 1990. Chromosome systems in American and Asian Trillium species by means of chromosome analyses. Plant Species Biol. 5: 67-72.

- 2001. The origin and evolution in Trillium. 1. The origin of the Himalayan Trillium govanianum. Cytologia 66: $105-111$.

— and Channell, R. B. 1975. Distribution and evolutionary significance of chromosome variation in Trillium ovatum. Evolution 29: 257-266.

- and Grant, W. F. 1979. Chromosome compositions of natural populations in Trillium grandiflorum. Science Reports of Tokyo Woman's Christian Univ. 45-47: 509-547.

- and Kozuka, Y. 1958. Evolution and variation in Trillium. V. A list of chromosome compositions of Trillium kamtschaticum. J. Fac. Hokkaido Univ., Ser. V., Bot. VI 3: 273-319.

Grant, V. 1981. Plant Speciation, 2nd (ed.). Columbia Univ. Press, N.Y.

Kihara, H. 1975. Origin of cultivated plants with special reference to wheat. Seiken Ziho 25-26: 1-24.

Kurabayashi, M. 1952. Differential reactivity of chromosomes in Trillium. J. Fac. Sci. Hokkaido Univ., Ser. V., Bot. VI 2: 233-247. 
Osaloo, S. K. and Kawano, S. 1999. Molecular systematics of Trilliaceae. II. Phylogenetic analyses of Trillium and Its allies using sequences of $r b c L$ and mat $K$ genes of $c p$ DNA and internal transcribed spacers of 18S-26SnrDNA. Plant Species Biol. 14: 75-94.

-, Ohara, M. and Kawano, S. 1999. Molecular systematics of Trilliaceae. I. Phytogenetic analyses of Trillium using mat $K$ gene sequences. J. Plant Research 112: 35-49.

Pope, G. G. 1995. The Influence of Climate and Geography on the Biocultural Evolution of the Far Eastern Hominids. In: Vrba, E. S. et al. (eds.). Paleoclimate and Evolution with Emphasis on Human Origins. Yale Univ. Press, New Haven.

Roberts, N. 1989. The Holocene-An Environmental History. Blackwell, Cambridge.

Stebbins, G. L. 1971. Chromosomal Evolution in Higher Plants. Edward Arnold, London.

- 1974. Flowering Plants-evolution above the Special Level. Harvard Univ. Press, Cambridge, Massachusetts.

Stewart, W. F. 1983. Paleobotany and the Evolution of Plants. Cambridge Univ. Press, Cambridge.

Takhtajan, A. 1981. Flowering Plants-Origin and Dispersal. Bishen Singh Mahendra Pal Singh, India.

Tsukada, M. 1974. Paleoecology II. Synthesis. Kyoritsu Publishers, Tokyo.

Watts, W. A. 1979. Late Quaternary Vegetation of Central Appalachian and the New Jersey coastal plain. Ecological Monographs 49: 427-469.

Wilson, G. B. and Boothroyd, E. R. 1941. Studies in differential reactivity: the rate and degree of differentiation in the somatic chromosomes of Trillium erectum L. Can. J. Res. 19: 400-412.

Wolfe, J. A. 1967. Neogene and Early Quaternary Vegetation of Northwestern North America and Northeastern Asia. In: Hopkins, D. M. (ed.). The Berling Land Bridge. Stanford Univ. Press, Stanford.

Wright, S. 1969. Evolution and the Genetics of Populations. Vol. 2. The Theory of Gene Frequencies. Univ. of Chicago Press, Chicago. 